\title{
Pedagógiai kihívások a Covid idején - Előszó
}

\author{
M. Pintér Tibor \\ Károli Gáspár Református Egyetem Bölcsészet- és Társadalomtudományi Kar \\ Magyar Nyelvtudományi Tanszék
}

2020 tavaszán a Covid19 hatására hazánkban is előtérbe került az online oktatás, amelynek köszönhetően új dinamizmussal tört be az informatikai és módszertani innováció az oktatás mindennapjaiba. A digitális oktatásra való átállás felgyorsította a reformok terjedését, olyan módszerek meghonosodását, amelyek a fejlett oktatási rendszerű országokban már bevált szokásként vannak jelen, ezzel eddig nem látott tempójú digitális fejlődésnek tette ki az érintett pedagógusokat, a diákokat és a szülőket. Bizonyos szempontból a digitális oktatás egy alternatív, egyéni tanulmányi úttá vált (Fekete \& Prokoláb, 2020; Vetési, 2020), amelynek során a pedagógus mint segítő, facilitátor jelenik meg a tanulási folyamatban (Prievara, 2020). Ugyanakkor a tantermen kívüli munkarendre történő átállás kényszere a szervezett oktatás olyan elemi feltételeit iktatta ki az oktatási rendszer egészéből, mint a személyes nevelö-gyerek, tanuló-tanár interakció. Az oktatás és nevelés lényegi alapfolyamatának módosításai, közvetítő médiumokra alapozása, 2020 márciusában a tanulásszervezés teljes újragondolását igényelte valamennyi oktatási intézményben.

Az online térbe költöztetett oktatás egyfelől pozitív hatással volt az oktatásinformatika fejlődésére, az oktatásinformatikai javak (eszközök, módszerek) terjedésére, ugyanakkor (feltehetően) negatív hatással volt az oktatás eredményességére, valamint a szociális nevelésre. Az online térbe vitt nevelés és oktatás gyakorlatait és különféle hatásait még vizsgáljuk, a Gyermeknevelés Tudományos Folyóirat a gyermeknevelést, illetve a gyermeknevelők oktatását érintő kutatásokból mutat be néhányat - mutatóul arról, hogy a folyamat utóhatásait több hazai kutatócsoport, több magyarországi műhely is vizsgálja.

A Covid-járványt és hatásait bemutató, oktatáshoz köthető kutatások prezentálása sokrétű folyóiratunk jelenlegi, 2021/2. számában. Az Olvasók találhatnak általánosabb elméleti keretbe helyezett, tágabb merítést bemutató tanulmányokat, a gyermeknevelést, a Covid-járvány alatti oktatást érintő gyakorlati pedagógiai megoldásokat bemutató műhelytanulmányokat, valamint a témához kapcsolódó szakirodalmi ismertetőket és egy online lebonyolított, témába illeszkedő konferencia összefoglalóját. 
A Tematikus tanulmányok rovat nyitótanulmányában Császár Lilla (2021) a járványhelyzet szülte bezártság pozitív, kreatív tapasztalataiból ad ízelítőt, amikor hazai és nemzetközi művészek, valamint az ELTE TÓK hallgatóinak vizuális művészeti produktumait mutatja be. Számos kreatív és találékony formáját annak, hogy a megváltozott társadalmi körülmények között hogyan látjuk a másikat és ömnagunkat. A tanulmány vizuális kalandra hív: az Art Challenge, a nagybetűs művészet "aprópénzre váltása", azaz a nemzetközileg is (el)ismert festmények mindennapi használati tárgyakkal történő megjelenítése, a KarantÉn projekt, a kreatív önkifejezés a számos projektek egyike a vizuális kultúra területéről, ahol a szociális szeparáció kifejezetten kreatív ötletekre sarkallta a művészeket (Császár, 2021). A koronavírus-járvány emberéleteket követelö, jelenleg is tartó időszaka alatt az emberi kreativitás és önkifejezés új és produktív módjai is kibontakozni látszanak. E tanulmány ízelítőt ad a művészet soha meg nem szűnő erejéből.

A digitális tanrend negatív hatása az általános és középiskolák tanulóin, illetve a felsőoktatás hallgatóin is megfigyelhető. A jelenléti oktatás hiánya azonban az oktatás legalsóbb szintjein feltehetően erősebben jelent meg. Józsa Krisztián és Pasztendorf Gabriella empirikus kutatásukban (Józsa \& Pasztendorf, 2021) azt vizsgálták, hogy a digitális munkarend folyamán milyen eredményességgel valósult meg a kezdő iskolai szakaszban az olvasástanítás. Első és második osztályban tanító pedagógusokat, valamint szülőket kértek arra, hasonlítsák össze az osztálytermi és a digitális olvasástanítást, illetve foglalják össze tapasztalataikat. A kutatás rávilágított arra, hogy a megkérdezett tanítók többsége a hagyományos olvasástanítási módszereket próbálta használni, adaptálni a digitális környezetbe, nem számolva azzal, hogy ezek a módszerek digitális környezetben csak részben lehetnek hatékonyak. Az online oktatás során alkalmazható új módszerek kidolgozása és elterjedése egyelőre még csak gyerekcipőben jár, ugyanakkor vannak e téren is feljesztések. Az olvasástanítás nehézségei azonban nem csak a tanító módszereit tükrözték, a pilotkutatás újra felhívta a figyelmet, hogy a tanítás sikertelensége sok esetben az informatikai eszközök vagy az internet vagy a nyugodt környezet hiányára vezethető vissza, hiszen a kutatás résztvevőinek 10-15\%-a számára a digitális munkarend nem volt elérhető. A szerzők megállapítják, hogy ebben a korban a szülőkkel való szoros együttműködés az olvasástanítás eredményessége szempontjából elengedhetetlen, azonban a szülők nagy hányadának nincs elegendő ideje és szakmai tudása ahhoz, hogy megfelelő mértékben segítse a gyermek olvasástanulását. Újra megerősítést nyert, hogy a hagyományos oktatást ma még nem lehet teljes mértékben helyettesíteni a tantermen kívüli digitális munkarenddel, főleg nem ebben a korosztályban (Józsa \& Pasztendorf, 2021). Az iskola kezdő szakaszában rendkívül fontos a pedagógus személye, a személyes találkozások, a pedagógus szakmai tudása mellett a hatékony tanítás és tanulás szempontjából.

Gyöngy Kinga a szülösegítés témájának magyarországi és nemzetközi szakirodalmát tekinti át, kitérve a szülősegítés különböző formáira, illet- 
ve azok hatásvizsgálataira (Gyöngy, 2021). A szakirodalmi áttekintésben különös hangsúly kerül a három éven aluli kisgyermekeket nevelö szülök támogatásának lehetőségeire. A tanulmány áttekinti a szülők támogatásának változatait, illetve a távsegítés hazai és nemzetközi lehetőségeit, ezek formáit és hatékonyságát. Az interneten keresztüli segítségnyújtás az elmúlt évtizedek egyik vívmánya, melynek fontosságára a Covid19-járvány miatti lezárások kényszerüsége is rámutatott. A tanulmány végén a távsegítés kapcsán a lehetséges távsegítő formák egy speciális formájáról, a szülőknek szóló tömeges nyílt online kurzusokról is szó esik, mintegy előrevetítve a mai oktatáspedagógiai folyamatokban rejlő lehetőségeket.

A koronavírus miatt előtérbe került online oktatás hatásait vizsgálva nem kizárólag a tanulás hatékonyságával, hanem a hatékonyságot befolyásoló motivációval is érdemes foglalkozni. Józsa Gabriella és munkatársai (Józsa et al., 2021) a vírushelyzet következtében létrejött online oktatás kapcsán vizsgálja a tanulási motivációt. Kutatásukban 160 általános iskolai és középiskolai pedagógus vett részt. Kutatásuk célja feltárni a pedagógusok vélekedését a diákok motiváltságáról a digitális oktatás folyamán. Összehasonlításukban kiderül, hogy a pedagógusok és a tanulók motiváltságában milyen különbséget látnak a pedagógusok az osztálytermi és a digitális oktatás során. Fontos tapasztalat, hogy a kezdő és a gyakorlott pedagógusok az online térben is sikeresnek érzik motiválási módszereiket. Úgy tűnik, hogy a digitális térben nem feltétlenül azok a pedagógusok tudnak sikeres motiválási módszereket alkalmazni, akik az osztálytermi környezetben sikeresek tudtak lenni. A tanulók motiváltságában csökkenés figyelhető meg az iskolafokozat, az életkor előrehaladtával mind a jelenléti, mind a digitális oktatás során. A szerzők hangsúlyozzák, hogy a tanulók motiváltsága és a pedagógusok motivációs stratégiáinak csökkenő eredményessége közötti kapcsolat feltárására további vizsgálatok szükségesek.

A járvány okozta bezártság (és bezárás) nem csak az oktatást érintette, általában hatással volt, hatással van a családok életére. A szülők arra kényszerültek, hogy kiskorú gyermekeikről otthon gondoskodjanak. Az otthonmaradt kisgyermekekkel való törődés sok esetben az infokommunikációs eszközök használatának gyakoribbá válását eredményezte. F. Lassú Zsuzsa és Megyeriné Fácska Judit kutatásában 391, hat év alatti gyermekeket nevelő szülő bevonásával vizsgálta a kisgyermekek médiaeszköz-használatával kapcsolatos általános és pandémia alatti nézeteit és gyakorlatait (F. Lassú \& Megyeriné Fácska, 2021). Eredményeik szerint a digitális eszközhasználat általános szabályozásával kapcsolatban négy faktort állapítottak meg, melyek közül a „megengedő, nem szabályozó" és az „ellenörzó, kontrolláló” faktorok mutattak összefüggést a járvánnyal összefüggő változásokkal. A kutatás eredményei a szülők tudatosságának fokozására hívják fel a figyelmet a kisgyermekek túlzott médiaeszköz használatával összefüggésben.

A digitális oktatás miatt az otthoni tanulás, illetve a szülő tanulásban vállalt felelőssége egyaránt új fénybe került. Az oktatás tulajdonképpen meg- 
újult vagy megújulni látszódó folyamatába a pedagógusoknak sem volt egyszerü "beletanulniuk", a szülők pedig saját munkájuk végzése mellett vettek részt gyermekeik tanulási folyamataiban. Amennyiben az óvoda-iskola váltás folyamán létezik úgynevezett gyengéd átmenet, érdemes lenne a pandémia okozta "belemerítési" folyamatot és pedagógiai váltást, pedagógiai átmenetet is vizsgálni. A közoktatásban dolgozó pedagógusok, valamint a felsőoktatásban dolgozó oktatók egyaránt közösségi fórumokon és online módszertani tréningeken igyekeztek segíteni egymásnak ebben a kényszerü pedagógiai váltásban (a magyarországi felsőoktatás váltásának nehézségeiről lásd például M. Pintér et al., 2021). Ez az időszak ugyanakkor a szülőket is kihívás elé állította, mert új kompetenciákat kellett elsajátítaniuk annak érdekében, hogy segíteni tudják gyermekeiket az online tanulási térben.

Bencéné Fekete Andrea feltáró kutatása (Bencéné Fekete, 2021) azt vizsgálja, miként alkalmazkodtak az alsó tagozatos gyerekek szülei $(\mathrm{N}=113)$ a váratlan új szerephez. A tanulmányból megtudhatjuk, milyen eszközöket, felületeket használtak a pedagógusok az online tanulás során, olvashatunk a pedagógus-szülögyermek kapcsolattartási formák müködéséről, valamint a tanulásirányítás, tanulástámogatás módjairól. A kutatás segítségével rálátásunk lehet a digitális iskola első pár hónapjában kialakult szülői tapasztalatokra.

Török Balázs és munkatársai az oktatási folyamatok másik központi szereplőit, az iskolavezetők szerepét vizsgálták a digitális oktatás folyamatában, annak sikerességében (Török et al., 2021). Kutatásukban a vezetői feladatok általános modelljeként az alábbi kulcsfeladatok ellátására fókuszáltak a tantermen kívüli munkarendre történő átállás időszakát megvizsgálva: 1. lehetőségelemzés, 2 . kapacitásépítés, 3. közvetítő médiumok választása, 4. tanulásszervezés elvárásrendszere, 5 . visszacsatolás alapú irányítás és 6 . az elérhetetlen tanulók problémájának kezelése.

A tematikus szám mủhelytanulmányai koránt sem kevésbé fontos témákat dolgoznak fel - a mühelyjelleg a téma fókuszált, kevésbé kontextualizált feldolgozottságára vonatkozik. A Tematikus tanulmányok központjában az ELTE TÓK oktatóinak jó gyakorlataiból olvashatunk - hogyan vészelte át a felsőoktatás e korszakot, illetve a tanítás előtt álló hallgatókat milyen tudással vértezik fel. Fontos tapasztalatok olvashatók az angol munkaközösség (Fenyődi et al., 2021; Trentinné Benkő \& Kovács., 2021), valamint a német munkaközösség a Covid idejére adaptált felsőoktatás-pedagógiai gyakorlatából (Baloghné Nagy et al., 2021; Miskei-Szabó, 2021) - rávilágítva egy-egy kisebb oktatói közösség, valamint az egyetemen müködő alkalmazkodási folyamatokra is. A mühelymunkák sorát a bölcsődei (Farkas et al., 2021) és óvodai gyakorlatok (Villányi, 2021) oktatáspedagógiai és intézményvezetési tapasztalatai, jó gyakorlatai zárják.

A tematikus szám egy oktatásinformatikai konferencia tanulságai (M. Pintér, 2021), illetve két friss, oktatásmódszertani (Földi, 2021), kutatásmódszertani kötet ismertetésével zárul (Takács, 2021).

A Gyemeknevelés Tudományos Folyóirat Oktatás a Covid idején című tematikus száma sokféleképpen olvasható: a mai, posztmodern irodalom ol- 
vasási szokásai mentén létezik egy denotatív, nyilvánvaló jelentés: az olvasók megtudhatják, milyen magyarországi kutatások indultak el a vírusjárvány okozta oktatási helyzet idején. A másodlagos, konnotatív jelentés már korántsem ennyire egyértelmü: a sorok között megannyi siker és kudarc, megannyi ötlet, segítségnyújtási módszer olvasható. Egy tágabb szociális közösség (pedagógusok) harca a tudásért, a tudásátadásért, küzdelem a fiatalokért és a jövőért. A jövőt ugyanis célzottan kell építeni, ennek egyik mérföldköve az oktatás. Ahogy az Írás tartja: "Boldog, aki felolvassa, és boldogok, akik hallgatják..." (Jel 1,3).

\section{Irodalom}

Baloghné Nagy, G, Miskei-Szabó, R \& Radvai, T. (2021). Erfahrungen über den Online-Unterricht während der Pandemie. Bericht der Fachgruppe Deutsch der Fakultät für Grundschul- und Kindergartenpädagogik der Eötvös-LorándUniversität. Gyermeknevelés Tudományos Folyóirat, (9)2, 332-353. https://doi. org/10.31074/gyntf.2021.2.332.353

Bencéné Fekete, A. (2021). Digitális oktatás a család szemszögéből. Gyermeknevelés Tudományos Folyóirat, (9)2, 205-226. https://doi.org/10.31074/gyntf.2021.2.205.226

Császár,L.(2021).CoronArt-Művészetakoronaidején.Gyermeknevelés Tudományos Folyóirat, (9)2, 97-130. https://doi.org/10.31074/gyntf.2021.2.97.130

F. Lassú, Zs. \& Megyeriné Fácska, J. (2021). „A tévé maradt az egyetlen lehetőség, ami lefoglalta őket" - Hatéves kor alatti gyermekek és családjuk digitális eszközhasználatának változása a Covid19 járvány idején. Gyermeknevelés Tudományos Folyóirat, (9)2, 187-204. https://doi.org/10.31074/gyntf.2021.2.187.204

Farkas, P., Schreindorfer, L. A., Szabó, G., Varga, Gy. \& Rausch, A. (2021). Digitális eszközhasználati szokások vizsgálata bölcsődés gyermekek és családjaik körében - Szülők kikérdezése a pandémia idején. Gyermeknevelés Tudományos Folyóirat, (9)2, 354-377. https://doi.org/10.31074/gyntf.2021.2.354.377

Flick-Takács, N. (2021). „Használati útmutató” a kutatói szemléletmód kialakításához a tudásalapú társadalmak pedagógusképzésében - Könyvismertetés. Gyermeknevelés Tudományos Folyóirat, (9)2, 408-412. https://doi.org/10.31074/gyntf.2021.2.408.412

Földi, F. (2021). Egy sajátos oktatási módszer kihívásai: Recenzió az Educational challenges in subject didactics education in the context of home education címü könyvről. Gyermeknevelés Tudományos Folyóirat, (9)2, 404-407. https://doi. org/10.31074/gyntf.2021.2.404.407

Fenyődi, A., Poros, A., Lo Bello, M. J., Kruppa, É., Árva, V. \& Trentinné Benkő, É. (2021). Online education and 'best' practices in foreign language teacher's education during the 2020/2021 lockdown period. Gyermeknevelés Tudományos Folyóirat, (9)2, 286-313. https://doi.org/10.31074/gyntf.2021.2.286.313

Gyöngy, K. (2021). Kisgyermeket nevelő szülők támogatásának hazai és nemzetközi lehetőségei, személyes és távsegítő formái - szakirodalmi áttekintés. 
Gyermeknevelés Tudományos Folyóirat, (9)2, 145-168. https://doi.org/10.31074/ gyntf.2021.2.145.168

Józsa, G., Karáné Miklós, N. \& Józsa, K. (2021). Pedagógusok tapasztalatai a tanulók motiválásáról a Covid19 járvány idején. Gyermeknevelés Tudományos Folyóirat, (9)2, 169-186. https://doi.org/10.31074/gyntf.2021.2.169.186

Józsa, K. \& Pasztendorf, G. (2021). Az olvasástanítás eredményessége az iskola kezdő szakaszában a Covid19 időszaka alatt: a pedagógusok és a szülők megítélése. Gyermeknevelés Tudományos Folyóirat, (9)2, 131-144. https://doi.org/10.31074/ gyntf.2021.2.131.144

M. Pintér, T. (2021). Oktatásinformatika a felsőoktatásban - Kooperáció és párbeszéd a jó gyakorlatok megteremtésében. Gyermeknevelés Tudományos Folyóirat, (9)2, 399-403. https://doi.org/10.31074/gyntf.2021.2.399.413

M. Pintér, T., Bodnár, É., Dósa, K., Dorner, H., Lénárt, K., Lengyelné Molnár, T., Gorana, M., Ollé, J, Rymarenko, M., Vörös, Z. \& Dringó-Horváth, I. (2021). Oktatásinformatikai helyzetkép a magyarországi felsőoktatásban. Új Pedagógiai Szemle, 71(3-4), 54-74.

Miskei-Szabó, R (2021). Az online oktatás tapasztalatai gyakorló pedagógusok és egyetemi hallgatók szemszögéből. A virtuális osztálytermek szerepe a tanításban. Gyermeknevelés Tudományos Folyóirat, (9)2, 314-331. https://doi.org/10.31074/ gyntf.2021.2.314.331

Török, B., Nagy, R., Imre, N. \& Révész, L. (2021). A tantermen kívüli, digitális tanulási munkarend az általános iskolákban - Az iskolavezetők szerepe az iskola szervezeti működésében. Gyermeknevelés Tudományos Folyóirat, (9)2, 227-255. https://doi.org/10.31074/gyntf.2021.2.227.255

Trentinné Benkő, É. \& Kovács, M. (2021). A tanítási gyakorlat alternatív megközelítései: jelenléti, távolléti és hibrid megoldások a koronavírus-járvány idején. Gyermeknevelés Tudományos Folyóirat, (9)2, 256-285. https://doi. org/10.31074/gyntf.2021.2.256.285

Villányi, Gy. (2021). A Covid19 járvány okozta életmódbeli változások hatásai az óvodahasználókra - Óvodapedagógusok és szülők tapasztalatainak áttekintése. Gyermeknevelés Tudományos Folyóirat, (9)2, 378-398. https://doi.org/10.31074/ gyntf.2021.2.378.398

M. Pintér Tibor: https://orcid.org/0000-0002-5212-4107 